\title{
SEA TURTLES IN ILAJE, NIGERIA: STATUS, SIGHTING PERIODS AND CONSERVATION AWARENESS
}

\author{
Johnson A. Ogunjobi", Olubunmi C. Surulere \\ Ondo State University of Science and Technology, Nigeria \\ *e-mail: ogunjonson02@gmail.com,ja.ogunjobi@osustech.edu.ng
}

Received: 12.05.2019. Revised: 26.12.2019. Accepted: 28.12.2019.

\begin{abstract}
Local understanding of migratory species is critical towards the global conservation agenda. The present study, conducted from 2016-2018, aimed to (i) examine the demographic characteristics of fishers operating within Ilaje axis in the Atlantic Ocean; (ii) determine species and status of sea turtles in the area; (iii) investigate their sighting periods; (iv) evaluate fishers' behaviour towards sea turtles; (v) assess fishers' sea turtles' conservation awareness; (vi) determine the roles of demographic factors on the fishers' level of sea turtles utilisation and conservation. A multi-stage sampling procedure was employed to select the study sites and respondents. The sample size consisted of 364 fishers from six communities. Data were collected using personal interviews, a structured questionnaire and direct observation. During each interview, photographs of six sea turtles reportedly found in Nigeria were presented for easy identification. Data collected were analysed using descriptive statistics, Pearson's correlation and multiple linear regressions. The results revealed that all fishers hunting along the Atlantic Ocean from Ilaje axis are male. The majority of them (97.2\%) are within the active age of 21-60 years old with over two-third of them educated $(81.0 \%)$. Two species of sea turtles (Lepidochelys olivacea, Dermochelys coriacea) are foraging in the area, although L. olivacea was mostly encountered. These sea turtles migrate into the area from April and vacate around October in each year. During this period, some L. olivacea individuals were accidentally trapped inside nets set for hunting crustaceans especially Malacostraca: Decapoda. About $92.3 \%$ of the accidental captured sea turtles had a good physical appearance with a body condition index of $1.77 \pm 0.09$ and $1.36 \pm 0.04$ in male and female, respectively. Accidentally captured sea turtles are consumed as meat indiscriminately. The predictors of sea turtles utilisation were fishers' age $(\beta=0.15, \mathrm{p}<0.05)$ and family size $(\beta=-0.02, \mathrm{p}<0.05)$ while the fishers' educational level is the predictor of sea turtles' conservation $(\beta=0.02, p<0.05)$. Also, the study showed that there were positive and significant relationships between fishers' personal factors and their rationale for capturing sea turtles $(r=0.23, p<0.01)$ and sea turtle's conservation awareness $(\mathrm{r}=0.22, \mathrm{p}<0.01)$. A low knowledge regarding sea turtles' conservation status and its non-consumptive benefits are suggested responsible for high indiscriminate consumption and little participation in its conservation. Urgent sea turtles' conservation awareness in the study area is hereby recommended.
\end{abstract}

Key words: aquatic animal, fishers' behaviour, migratory species, Ondo State, sea turtles' conservation

\section{Introduction}

The marine environment produces valuable living and non-living resources which are in most cases used by human indiscriminately (Holligan, 1995). Because of this, sea turtles received a growing research interest globally. In Africa, similar studies were conducted along the Atlantic Ocean (Catry et al., 2002; Fretey et al., 2002; Formia et al., 2003). Some studies on nesting ecology and by-catch in sea turtles were also reported from Nigeria (Solarin et al., 2009; Adegbile et al., 2013, 2015).

In Ondo State, Nigeria, about $80 \%$ of the people living around the coastal area are engaged in fishing (Babatunde, 2010). In Ilaje area of Ondo State, fishing is an important component for the survival of the people. These people are engaged in fishing venture regularly almost on daily bases. In doing so, they encountered several aquatic species of economic, ecological and conservation interest.
The encountered species are either residential or migratory. There is a lack of studies on perception and behaviour of fishers towards utilisation and conservation of the migratory species under different categories of threat as made available by International Union for Conservation of Nature (IUCN) in Ilaje. This may be connected with current unregulated and unsustainable fishing activities in this area. Biological resources are of immense value (Cafaro \& Primack, 2001). To avoid their extinction, information about them, their uses and conservation awareness by local people is crucial. Interestingly, when knowledge is on the increase, more positive attitudes toward conservation are developed (Wilson \& Tisdell, 2005).

Five species of sea turtles (Caretta caretta (Linnaeus, 1758), Chelonia mydas (Linnaeus, 1758), Lepidochelys olivacea (Eschscholtz, 1829), Eretmochelys imbricata (Linnaeus, 1766), and 
Dermochelys coriacea (Vandelli, 1761)) are found in Nigerian waters (Amadi, 1991). Despite the fact that Nigeria is one of the signatory to memorandum of understanding on conservation of marine turtles on the Atlantic coast of Africa, people living in Ilaje along the Atlantic Ocean still consume these animals. Different research on sea turtles along the Atlantic coast was carried out in countries such as Equatorial Guinea (Tomás et al., 1999), Angola (Carr \& Carr, 1991) and Guinea Bissau (Catry et al., 2002) to mention very few data.

Since sea turtles are migratory species, information on their species composition and status at local level across the globe is imperative just as understanding fishers' perception and activities as regards the animal (de Carvalho et al., 2016; Awabdi et al., 2018). The aim of the present paper was to (i) examine the demographic characteristics of fishers' operating in Ilaje; (ii) determine species and status of sea turtle in the area; (iii) investigate their migratory periods; (iv) evaluate fishers' behaviour towards sea turtles; (v) assess fishers' sea turtles' conservation awareness and participation; (vi) determine the role of demographic factors on the fishers' level of sea turtles utilisation and conservation.

\section{Material and Methods}

Ilaje, covering a total area of $1318 \mathrm{~km}^{2}$, is situated within the southern part of Ondo State, South-western Nigeria $\left(5.8333^{\circ}-6.2500^{\circ} \mathrm{N} ; 4.5000^{\circ}-5.1667^{\circ} \mathrm{E}\right)$ (Fig. 1). The area supports a wide range of aquatic animals (Babatunde, 2010). These abundant aquatic resources are the primary source of livelihood for people in the area (Ashiru et al., 2017).

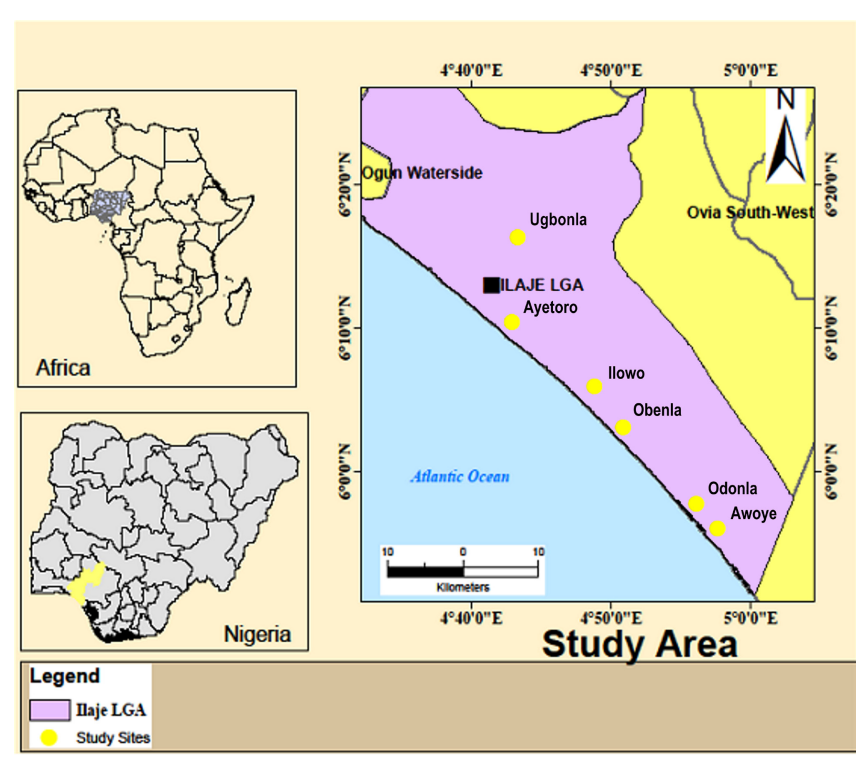

Fig. 1. Locations of the selected fishers' communities along the Atlantic Ocean within Ilaje local government area, Ondo State, South-western Nigeria with the sign of sea turtle foraging site.

\section{Data collection and analysis}

The studied population consisted of the fishers along the Atlantic Ocean within Ilaje axis, Ondo State, Nigeria. The study was conducted in three stages. Stage 1 was a preliminary study of Ilaje area in July - December 2016 aimed to familiarise with the study area. During stage 2, a minimum of five sea turtles as by-catch per fisher in the year 2016 and 2017 was declared for fishers' inclusion in this study. Based on this preliminary data, fishers from six communities were purposively selected. The selected communities were Awoye $\left(5.916667^{\circ} \mathrm{N}, 4.966667^{\circ} \mathrm{E}\right)$, Ayetoro $\left(6.100000^{\circ} \mathrm{N}\right.$, $\left.4.783333^{\circ} \mathrm{E}\right)$, Ilowo $\left(6.050000^{\circ} \mathrm{N}, 4.850000^{\circ} \mathrm{E}\right)$, Obenla $\left(6.016667^{\circ} \mathrm{N}, 4.883333^{\circ} \mathrm{E}\right)$, Odonla $\left(5.933333^{\circ} \mathrm{N}\right.$, $\left.4.950000^{\circ} \mathrm{E}\right)$ and Ugbonla $\left(6.150000^{\circ} \mathrm{N}, 4.800000^{\circ} \mathrm{E}\right)$.

In the third stage, fishers from the purposively selected communities were randomly sampled. The sample size obtained consisted in total of 364 fishers. Data were obtained from January 2017 to December 2018 by means of a structured questionnaire, a personal interview and an on-site assessment. Each interview took 20 min. between Monday and Thursday only while the on-site assessment was conducted on Friday and Saturday (14:00-18:00 h) after the fishers returned from their fishing trips. Each study site was visited once a month (i.e. 24 visits per community; 144 visits in all). The fishers were individually interviewed to avoid interference from others. The research questions covered the fishers' demographic characteristics (age, family size and educational level) which were the independent variables and sea turtles' utilisation and conservation which constituted the dependent variables.

A modified visual stimulus as used by Ogunjobi et al. (2018) with coloured pictures of five species of sea turtle reported in Nigeria (Amadi, 1991) was also presented to the fishers during the interview to ascertain species of sea turtles in the study area. The on-site assessment was used to substantiate fishers' responses.

The status of the sighted seaturtles was determined through physical appearances, morphometric analysis and body condition index (BCI) following the Bjorndal et al. (2000) procedure. Individual physical body appearances of the opportunistic by-catch were observed visually. Their sex was identified through direct observations of the gonads in situ as suggested by McCoy et al. (1983). The weight of the animal was measured with the use of a hang spring scale with 0.1 $\mathrm{kg}$ accuracy. The straight carapace length (SCL) was also measured using a wooden vernier caliper while BCI scores were calculated using the equation of «weight $\left.[\mathrm{kg}] / \mathrm{SCL}[\mathrm{cm}]^{3}\right) \times 10000$ » according to 
Bjorndal et al. (2000). All analyses were performed using the Statistical Package for Social Science (SPSS) version 22. The data obtained were analysed using descriptive statistics (frequency distribution, percentages, pie-chart and bar chart), Pearson's correlation and linear multiple regression.

\section{Results and Discussion \\ Demographic characteristic of fishers'} hunting Ilaje

All the fishers sampled (364) in connection with sea turtle in the area are male (Table 1). This finding corroborates with a similar study about a fishing crew in Ghana (Alexander et al., 2017). Over two-third of the fishers $(73.0 \%)$ were in their active age (21-40 years old). This observation is similar to Okayi et al. (2012) observations reporting that people who engaged in similar hunting venture are within $21-40$ years old. A higher proportion (81\%) of fishers are educated although most of them $(39.3 \%)$ had a primary school certificate, followed by those with senior secondary school education $(28.0 \%)$ while those who attended tertiary institutions were $13.7 \%$. The present study confirmed the position of Adeparusi et al. (2003), that about $67.5 \%$ of fishers in Ilaje, Ondo State, Nigeria were literate having primary, secondary or higher education. This study also agreed with the submission from Malaysia and Bangladesh (Teitze et al., 2005).

\section{Species and status of sea turtles found in Ilaje}

During our on-site assessment (July 2017 October 2018), Lepidochelys olivacea turtles were observed as by-catch in Awoye $(\mathrm{n}=8)$, Ayetoro $(\mathrm{n}=$ 5), Ilowo $(n=6)$, Obenla $(n=4)$, Odonla $(n=7)$, and Ugbonla $(n=9)$. Fishers from Ugbonla community recorded the highest value $(23.1 \%)$, followed by those from Awoye $(20.5 \%)$, while fishers in Obenla had the least value $(10.3 \%)$. The number of sea turtles obtained in this study technically agreed with Solarin et al. (2009), declaring five to twenty-five sea turtles being captured per canoe per year.

However, the interviews with the fishers revealed that two species of sea turtles (Lepidochelys olivacea and Dermochelys coriacea) are found in area. Of them, L. olivacea is mostly captured. This finding is similar to the finding of Adegbile et al. (2015) where it was stated that $L$. olivacea turtles are the most frequently observed sea turtles in Lagos and Nigeria. A similar study in Ghana also discovered these two sea turtle species (Alexander et al., 2017) and Eretmochelys imbricata in Cameroon (Fretey et al., 2002). However, Formia et al. (2003) mentioned that six Atlantic sea turtle species are found from Morocco to South Africa.
Table 1. Demographic characteristics of fishers in Ilaje $(\mathrm{N}=364)$

\begin{tabular}{lcc}
\hline Indicator & Frequency & Percentage (\%) \\
\hline Sex & 364 & 100 \\
Male & 0 & 0 \\
Female & & \\
Religion & 364 & 100 \\
Christianity & 0 & 0 \\
Islam & 0 & 0 \\
Traditional & & \\
Age category & 125 & 34.3 \\
21-30 & 141 & 38.7 \\
31-40 & 88 & 24.2 \\
$41-50$ & 10 & 2.8 \\
51-60 & & \\
Family size & 156 & 42.9 \\
1-2 & 104 & 28.6 \\
3-4 & 90 & 24.7 \\
5-6 & 14 & 3.9 \\
7-8 & & \\
Educational Qualification & 143 & 39.3 \\
Primary School & 102 & 28.0 \\
Secondary School & 50 & 13.7 \\
Tertiary Institution & 69 & 19.0 \\
Uneducated & &
\end{tabular}

Sex and morphometric characteristics of Lepidochelys olivacea submitted for evaluation during 144 visits across the study sites. Of the 39 specimens of $L$. olivacea sighted, ten were male $(\mathrm{BW}=19.45 \pm 1.41 \mathrm{~kg}, \mathrm{SCL}=47.09 \pm 4.07 \mathrm{~cm}$ and $\mathrm{BCI}=1.36 \pm 0.04$ ), while 29 were female $(\mathrm{BW}=22.51 \pm 2.67 \mathrm{~kg} ; \mathrm{SCL}=52.07 \pm 5.37 \mathrm{~cm}$; $\mathrm{BCI}=1.77 \pm 0.09)$. Based on sex, morphometric characteristics of the animals evaluated were not significantly different $(p>0.05)$. They were within the categories of sub-adult L. olivacea reported by Espinoza-Romo et al. (2018) and also resemble a reported population structure in northern Sinaloa, Mexico (Zavala-Norzagaray et al., 2014). In this study, the SCL was slightly lower compared with 69.7 $\mathrm{cm}$ reported by Adegbile et al. (2015). The calculated BCI was an indication of healthy animals as postulated by Kircher \& Wyneken (2017). Of the 39 specimens of $L$. olivacea submitted for evaluation, two males and one female were observed with varying degrees of injuries at the neck, fore and hind limbs regions (Table 2). The apparent morphometric analysis of sea turtles observed in this study is from an opportunistic observation and is likely to be substantially high.

\section{Sighting periods of sea turtles in Ilaje}

The perception of fishers and their by-catch were used to determine the periods at which sea turtles are sighted in this study. This species was sighted from late April to October. This is the period when the quantity of crustaceans (Malacostraca: Decapoda), a prey species for sea turtles, also increase as observed 
during the on-site assessment. This observation corroborates with Wildermann \& Barrios-Garrido (2012) findings. The fishers equally established that the more the quantity of the subphylum crustaceans harvested in the area, the higher the number of sea turtles in fishers' by-catch. It was also gathered that the majority of the food content in the alimentary canal / digestive track of the slaughtered sea turtle are crustaceans. The presence of Lepidochelys olivacea in the area for about five months (April - October) may suggest that the study location is a foraging site for this species. During this period, sea turtles are trapped as they tried to feed on the crustaceans inside the net. Fishers' perception also corroborated our surveillance (Fig. 2). This opinion is in line with the findings of Colman et al. (2014) that sea turtles are bottom inhabitants feeding on crustaceans.

\section{Fishers' behaviour towards sea turtles in Ilaje}

The majority (97\%) of the fishers affirmed that the by-catch sea turtles were accidentally captured. Sea turtles are entangled inside nets set for hunting smaller aquatic animals especially from the subphylum crustacean. Unfortunately, since immemorial times, all these fishers developed a strong need for consumptive use of the animals as about $73.9 \%$ of them conceitedly mentioned during

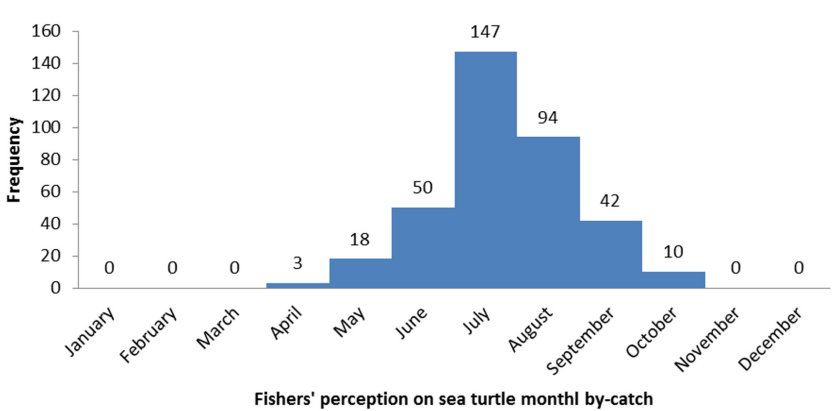

Fig. 2. The frequency of sea turtles perceived in by-catch per month in Ilaje. the interview that they slaughtered any captured sea turtles immediately after returning from hunting trips. Occasionally, $26.1 \%$ of the fishers preferred to sell their captured animal to complement economic loss caused by sea turtles visits into the nets (Table 3 ). At least, a whole captured sea turtle is sold for a price tag ranging from about 28 USD to 56 USD (as in April 2019) depending on the size of the animal and the need for food. The fishers' unsustainable consumptive behaviour was further observed during the on-site assessment in Awoye community (Fig. 3 ). Sales of sea turtles observed in this study was comparable to the submission of Weiss \& Kenneth (2002) and Barrios-Garrido et al. (2017) where it was stated that the black market trade in eggs and meat of sea turtles is a major threat to the animal in coastal environment around Latin America.

Fig. 3 demonstrates one of the captured female of Lepidochelys olivacea with eggs. Unfortunately, no nesting site was either previously reported or sighted during this study. This further stressed that Ilaje is a feeding site for this aquatic animal. Females with eggs may suggest a proximity of the area to a breeding or nesting site in Lagos State, Nigeria, noted by Adegbile et al. (2015). Noteworthy, some of the fishers temporarily kept their by-catch within their communities till the need arises.

Table 3. Fishers' behaviour towards captured sea turtles in Ilaje

\begin{tabular}{|c|c|c|}
\hline Variables & Frequency & Percentage \\
\hline $\begin{array}{l}\text { Mature captured animal was returned } \\
\text { back into the sea immediately }\end{array}$ & - & - \\
\hline $\begin{array}{l}\text { Captured animal was slaughtered } \\
\text { immediately or keep for short time } \\
\text { irrespective of size }\end{array}$ & 269 & 73.9 \\
\hline $\begin{array}{l}\text { Captured animal was sold } \\
\text { occasionally }\end{array}$ & 95 & 26.1 \\
\hline Total & 364 & 100 \\
\hline
\end{tabular}

Table 2. Physical examination of opportunistic encountered Lepidochelys olivacea in Ilaje

\begin{tabular}{|c|c|c|c|c|c|}
\hline \multirow{2}{*}{ Communities } & \multicolumn{2}{|c|}{ Sex } & \multirow{2}{*}{$\begin{array}{c}\text { Number } \\
\text { injured }\end{array}$} & \multirow{2}{*}{$\begin{array}{l}\text { Position of injuries } \\
\text { on the animal body }\end{array}$} & \multirow{2}{*}{ Remarks } \\
\hline & Male & Female & & & \\
\hline Awoye & 3 & 5 & - & No physical injury sighted in both sex & $\begin{array}{l}\text { Prompt attention and careful separation resulted } \\
\text { into no injury }\end{array}$ \\
\hline Ayetoro & 1 & 4 & 1 male & $\begin{array}{l}\text { Physical injuries sighted at both fore } \\
\text { limbs and neck region }\end{array}$ & $\begin{array}{l}\text { Injuries sustained during the removal of the animal } \\
\text { from the fishing net. }\end{array}$ \\
\hline Ilowo & 2 & 4 & $\begin{array}{l}1 \text { male, } 1 \\
\text { female }\end{array}$ & $\begin{array}{l}\text { Physical injuries sighted at both fore } \\
\text { and hind limbs of both sexes }\end{array}$ & The injuries sustained before the arrival of the fishers' \\
\hline Obenla & 1 & 3 & - & No physical injury sighted in both sex & $\begin{array}{l}\text { Prompt attention and careful removal of the sea } \\
\text { turtle from the fishing net }\end{array}$ \\
\hline Odonla & 1 & 6 & - & No physical injury sighted in both sex & $\begin{array}{l}\text { Prompt attention and careful removal of the sea } \\
\text { turtle from the fishing net }\end{array}$ \\
\hline Ugbonla & 2 & 7 & - & No physical injury sighted in both sex & $\begin{array}{l}\text { Prompt attention and careful removal of the sea } \\
\text { turtle from the fishing net }\end{array}$ \\
\hline Total & 10 & 29 & $2 \mathrm{M}: 1 \mathrm{~F}$ & & \\
\hline
\end{tabular}




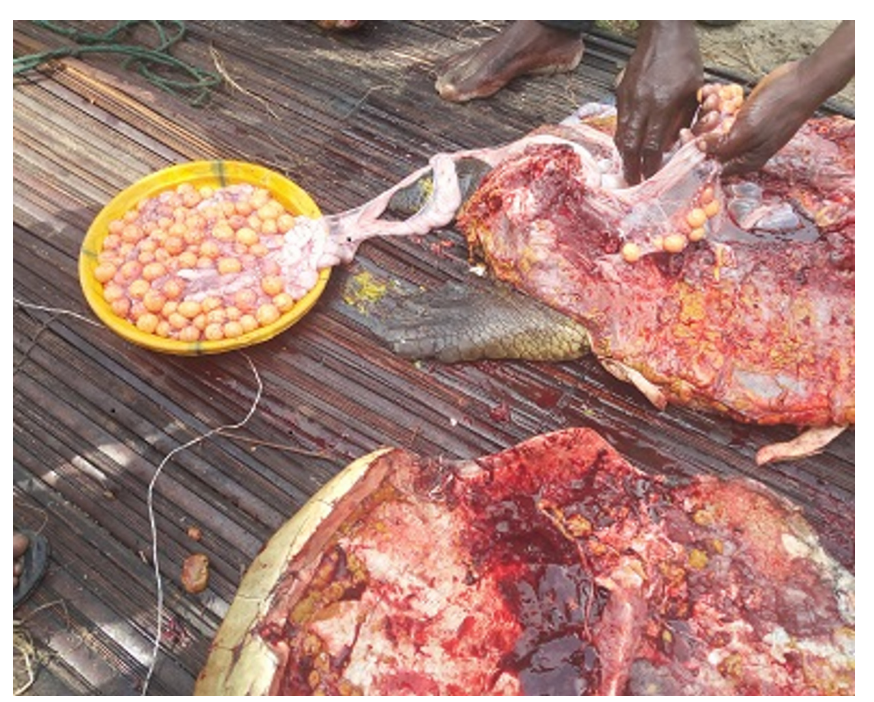

Fig. 3. Female sea turtle slaughtered immediately after a fishing trip in Ilaje.

However, sales of sea turtle are gender friendly in the study area as both male and female are involved in these. This observation is similar to Adebayo \& Pitan (2003), stating that about 64.2\% women are actively involved in turtle marketing. In Ilaje, sea turtles are only consumed as meat. Elsewhere, these animals are known to be highly utilised in zoo-therapy and alternative medicine (Begossi et al., 2004) as well as in communities in the southeast of São Paulo (Begossi \& Braga, 1992) and in Rio Tocantins (Begossi \& Braga, 1992). Fat of sea turtles are used for the treatment of asthma, bronchitis and arthritis (Seixas \& Begossi, 2001) due to their costless price within the area. Our finding is contrary to what was obtained by Barrios-Garrido et al. (2018) in Guajira Peninsula, Venezuela. This is connected with the abundance of food material available to sea turtles in Ilaje waters. The situation in Ghana differs as fishers always captured sea turtle during dry season in the area (Alexander et al., 2017). Further research is needed to clarify what drives this lethal use.

Levels of fishers' sea turtles conservation awareness and participation

The data presented in Table 4 show a low level of sea turtle's conservation awareness among the fishers in Ilaje. A very small proportion of the fishers $(19.2 \%)$ had information about sea turtle's conservation through their educational exposure. Despite this, none of the fishers was willing to return accidentally captured sea turtles regardless of its size or sex. This suggests that in this area, education attainment of the fishers was not completely translated into sea turtle's conservation. This may be connected with the quality and frequency of such information. It was further gathered that in Ilaje, all the educated fishers subscribed to internet facilities using one or a combination of phone networks (Table 5). As a result of this, 56 of the total respondents are privileged to some conservation information about sea turtles particularly on Facebook even though scanty. This is consistent with the findings reportingsocial media as the most popular sites used by internet subscribers (Duggan \& Brenner, 2013). According to Vieweg et al. (2010), information shared on social media may improve situational awareness and help people to collect useful information for decision making. Schroeder et al. (2013) opined that the use of social media networks like Facebook can be disseminated to vast networks quickly and across governance scales. Ors (2012) observed that social media can be considered as a «school of the air» where people gain knowledge on environmental protection.

\section{Relationships between the selected independent and dependent variables}

The fishers' age $(\beta=0.15, \mathrm{p}<0.05)$ and family size $(\beta=-0.02, p<0.05)$ were the predictors of sea turtle's utilisation. The study further detected that the educational level $(\beta=$ $0.02, p<0.05$ ) was the only determinant of sea turtles' conservation awareness of the fishers (Table 6). This confirmed that other personal factors (i.e. age and family size) had no significant relationship with fishers' sea turtle conservation awareness. The $\mathrm{R}^{2}(0.02)$ implies that this model explained $2 \%$ of the variation in the relationship between the personal factors of the fishers and their conservation awareness. Thus, educational background accounted for $2 \%$ of the variation in the relationships between the personal factors of the fishers and their sea turtle conservation awareness (Table 6).

A correlation test showed that there was a positive and significant relationship between fishers' personal factors and their rationale for capturing sea turtles $(r=0.23, p<0.01)$ (Table 7). This could be a result of lack of information about sea turtle's conservation in the study area. This study further revealed a positive and significant relationship between the fishers' personal factors and sea turtle's conservation awareness $(r=0.22$, $p<0.01)$. This suggests that a fisher subscribed to internet gets aware more frequently on sea turtles's conservation. 
Table 4. Levels of fishers' sea turtles conservation awareness

\begin{tabular}{lcc}
\hline Variable & Frequency & Percentage, \% \\
\hline Aware & 70 & 19.2 \\
Not aware & 294 & 80.8 \\
\hline Total & 364 & 100 \\
\hline
\end{tabular}

Table 5. Fishers' sources of information regarding sea turtles conservation awareness $(\mathrm{N}=70)$

\begin{tabular}{lcc}
\hline \multicolumn{1}{c}{ Variable } & Frequency & Percentage, $\%$ \\
\hline Social media & 56 & 80.0 \\
Personal contact & 12 & 17.1 \\
School activities & 2 & 2.9 \\
\hline Total & 70 & 100 \\
\hline
\end{tabular}

Table 6. Relationships between fishers' personal factors and their sea turtles' utilisation and conservation

\begin{tabular}{lcccc}
\hline \multicolumn{1}{c}{ Variables } & \multicolumn{2}{c}{ Utilisation level } & \multicolumn{2}{c}{ Conservation awareness } \\
Age & $\beta$ & $\mathrm{t}$ values & 0.04 & 0.11 \\
Family size & 0.15 & $2.89^{*}$ & 0.19 & 0.35 \\
Educational level & -0.02 & $-1.81^{*}$ & 0.02 & $0.00^{*}$ \\
$\mathrm{R}$ & 0.02 & 1.65 & 0.46 & - \\
$\mathrm{R}^{2}$ & 0.20 & - & 0.21 & - \\
$\mathrm{R}^{2}$ (adj) & 0.04 & - & 0.20 & - \\
$\mathrm{df}$ & 0.03 & - & 363 & - \\
\hline Note: $* \mathrm{p}<0.05$ & 363 & - & &
\end{tabular}

Table 7. Correlation matrix on relationships between fishers' personal factors and selected variables

\begin{tabular}{|c|c|c|c|}
\hline Variables & Correlation values (r) & $\mathrm{p}$ & Decision \\
\hline Rationale for capturing sea turtles & $0.23 * *$ & 0.00 & $\mathrm{~S}$ \\
\hline Behaviour towards captured sea turtles & 0.04 & 0.50 & NS \\
\hline Awareness on sea turtle conservation & $0.22 * *$ & 0.00 & S \\
\hline Sources of awareness on sea turtle conservation & -0.08 & 0.13 & NS \\
\hline
\end{tabular}
Note: ${ }^{* *} \mathrm{p}<0.01 ; \mathrm{S}-$ Significantly different; NS - Not Significantly different.

\section{Conclusions}

The effort towards the documentation of the status of sea turtles, their sighting period and conservation in Ilaje (Ondo State, Southwestern Nigeria) is timely. This study observed that in Ilaje, sea turtles have been collected predominantly by males between the ages of 21-40 years. The respondents claimed that in the study area, Lepidochelys olivacea and Dermochelys coriacea are present. However, an on-site assessment discovered only $L$. olivacea turtles. The physical appearance of most of the encountered animals was good according to sightings between April and October of each year. Despite these aquatic animals were captured accidentally, none of the fishers was willing to return their catch. The catch either ended in the pots of the fishers or sold entirely at the local market. This study equally observed that necessary information for the conservation of these migratory species is very scanty at the local level. It is not translated into fishers being friendly to sea turtles and their willingness to participate in their conservation.

\section{Recommendations}

This study encourages more detailed information regarding sea turtles' habitat utilisation in Ilaje. In the study area, the promotion of sea turtle conservation education using relevant governmental, non- governmental, professional bodies and individuals is urgently advocated. The concerted effort is hereby needed for sea turtles' conservation information to be translated into fishers' involvement.

\section{Acknowledgements}

We are indebted to many colleagues and students from Ilaje Local Government Area who renders assistance and suggestions before, during and after this study. We are particularly grateful to our volunteer Mr. Luro Babatunde (Awoye community), Dr. Pelemo, John and Mr. Chukwuka Friday (GIS unit, Forestry Research Institute of Nigeria, Ibadan, Oyo State, Nigeria) for the service they rendered.

\section{References}

Adebayo O., Pitan O.O. 2003. The role of women in marketing of frozen fish in Lagos State of Nigeria. In: $16^{\text {th }}$ Annual Conference of the Fisheries Society of Nigeria (FISON). Maiduguri, Nigeria. P. 156-160.

Adegbile O.M., Solarin B.B., Williams A.B., Oshisanya K.I., Olakolu F.C. Omogoriola H.O. 2013. Evidence of sea turtles nesting in Lagos, South-Western Nigeria. In: T. Tucker, L. Belskis, A. Panagopoulou, A. Rees, M. Frick, K. Williams, R. LeRoux, K. Stewart (Eds.): Proceedings of the thirty-third annual symposium on sea turtle biology and conservation. NOAA Technical Memorandum. No NOAA NMES-SEESC-645. 263 p.

Adegbile O.M., Olakolu F.C., Obienu J., Awosanya S. 2015. Sea turtles still nest in Lagos, Southwestern Nigeria. African Sea Turtles Newsletter 3: 17-20. 
Adeparusi E.O., Ajibefun A.I., Akeremale E.O. 2003. Smokecuring of fish by artisanal fisherfolks in Ilaje, Ondo State, Nigeria. Asset Series A 3(4): 101-109.

Alexander L., Agyekumhene A., Allman P. 2017. The Role of Taboos in the Protection and Recovery of Sea Turtles. Frontiers in Marine Science 4: 237. DOI: 10.3389/ fmars.2017.00237

Amadi A.A. 1991. The coastal and marine environment of Nigeria-Aspect of ecology and management. NIOMR Technical Paper. 76 p.

Ashiru O.R., Adegbile M.O., Ayeku P.O. 2017. Assessment of the Effect of Anthropogenic Activities on Aquatic Life in Ugbo-Aiyetoro Water-way, Southwestern Nigeria. International Journal of Oceanography and Marine Ecological System 6(2): 9-22. DOI: 10.3923/ijomes.2017.9.22

Awabdi D.R., Tavares D.C., Bondioli A.C.V., Zappes C.A., Di Beneditto A.P.M. 2018. Influences of conservation action on attitudes and knowledge of fishermen towards sea turtles along the southeastern Brazil. Marine Policy 95: 57-68. DOI: 10.1016/j.marpol.2018.06.024

Babatunde A. 2010. The impact of oil exploitation on the socio-economic life of the Ilaje-Ugbo people of Ondo State, Nigeria. Journal of Sustainable Development in Africa 12(5): 61-84.

Barrios-Garrido H., Espinoza-Rodríguez N., RojasCañizales D., Palmar J., Wildermann N., MontielVillalobos M.G., Hamann M. 2017. Trade of marine turtles along the Southwestern Coast of the Gulf of Venezuela. Marine Biodiversity Records 10(1): 15. DOI: 10.1186/s41200-017-0115-0

Barrios-Garrido H., Palmar J., Wildermann N., Rojas-Cañizales D., Diedrich A., Hamann M. 2018. Marine turtles presence in the traditional pharmacopoeia, cosmovision, and beliefs of Wayuú Indigenous people. Chelonian Conservation and Biology 17(2): 177-186. DOI: 10.2744/CCB-1276.1

Begossi A., Braga F.M. 1992. Food taboos and folk medicine among fishermen from the Tocantins River (Brazil). Amazoniana 12(1): 101-118.

Begossi A., Hanazaki N., Ramos R.M. 2004. Food chain and the reasons for fish food taboos among Amazonian and Atlantic forest fishers (Brazil). Ecological Applications 14(5): 1334-1343. DOI: 10.1890/03-5072

Bjorndal K.A., Bolten A.B., Chaloupka M. 2000. Green turtle somatic growth model: evidence for density dependence. Ecological Applications 10(1): 269-282. DOI: 10.1890/1051-0761(2000)010[0269:GTSGME]2.0.CO;2

Cafaro P.J., Primack R.B. 2001. Ethical issues in biodiversity protection. In: S.A. Levin (Ed.): Encyclopedia of Biodiversity. Vol. 2. San Diego: Academic Press. P. 593-555.

Carr T., Carr N. 1991. Surveys of the sea turtles of Angola. Biological Conservation 58(1): 19-29. DOI: 10.1016/00063207(91)90042-8

Catry P.C., Barbosa B., Indjai A., Almeida B.J., Godley J.C., Vié J.C. 2002. First census of the green turtle at Poilão, Bijagós Archipelago, Guinea-Bissau: the most important nesting colony on the Atlantic coast of Africa. Oryx 36(4): 400-403. DOI: 10.1017/S0030605302000765

Colman L.P., Sampaio C.L.S., Weber M.I., de Castilhos J.C. 2014. Diet of Olive Ridley Sea Turtles, Lepidochelys olivacea, in the Waters of Sergipe, Brazil. Chelonian Conservation and Biology 13(2): 266-271. DOI: 10.2744/CCB-1061.1

de Carvalho R.H., Mamede N., Bastos R.R., de Sousa B.M. 2016. Attitudes towards conservation and fishing interaction with sea turtles in the southeast coast of Brazil. Ocean and Coastal Management 127: 55-62. DOI: 10.1016/j. ocecoaman.2016.04.011

Duggan M., Brenner J. 2013. The Demographics of Social Media Users - 2012. Washington: Pew Research Center's Internet and American Life Project. Available from: http://www.hodasandassociates.com/wp-content/uploads/2013/02/PIP_SocialMediaUsers.pdf

Espinoza-Romo B.A., Sainz-Hemandez J.C., Ley-Quinonez C.P., Hart C.E., Leal-Moreno R., Aguirre A.A., ZavalaNorzagaray A.A. 2018. Blood biochemistry of olive ridley (Lepidochelys olivacea) sea turtles foraging in northern Sinaloa, Mexico. PloS ONE 13(7): e0199825. DOI: 10.1371/journal.pone.0199825

Fretey J., Meylan A., Tiwari M. 2002. The occurrence of the hawksbill turtle (Eretmochelys imbricata) in West Africa. In: A. Mosier, A. Foley, B. Brost (Eds.): Proceedings of the Twentieth Annual Symposium on Sea Turtle Biology and Conservation. NOAA Technical Memorandum. No NMFS-SEFSC-477. P. 95-96.

Formia A., Tiwari M., Fretey J., Billes A. 2003. Sea turtle conservation along the Atlantic coast of Africa. Marine Turtle Newsletter 100: 33-37.

Holligan P.M. 1995. Global overview of environmental change in coastal zones. Proceedings of International Conference Coastal change-95. Bordomer-IOC (Bordeaux, 1995). Bordeaux. P. 10-11.

Kircher L., Wyneken J. 2017. Sex Estimation by Geometric Morphometric Analysis of Loggerhead (Caretta caretta) Sea Turtle Hatchlings. Marine Turtle Newsletter 154: 12-15.

McCoy C.J., Vogt R.C., Censky E.J. 1983. Temperature-controlled sex determination in the sea turtle Lepidochelys olivacea. Journal of Herpetology 17(4): 404-406. DOI: $10.2307 / 1563594$

Ogunjobi J.A., Owolabi D.O., Adejoye A.F. 2018. Avifauna Identification and Habitat Utilization Knowledge among Secondary School Students in Okitipupa, Ondo State, Nigeria. Nigerian Journal of Wildlife Management 2(2): 13-20.

Okayi R.G., Ataguba G.A., Mbata F.U. 2012. Stock assessment of shrimps and prawn species of the lower Benue and Niger River, Nigeria. Journal of Agricultural Research and Development 2(4): 92-95.

Ors F. 2012. Environmental education and the role of media in environmental education in Turkey. Procedia Social and Behavioral Sciences 46: 1339-1342. DOI: 10.1016/j.sbspro.2012.05.298

Schroeder A., Pennington-Gray L., Donohoe H., Kiousis S. 2013. Using Social Media in Times of Crisis. Journal of Travel and Tourism Marketing 30(1-2): 126-143. DOI: 10.1080/10548408.2013.751271

Seixas C.S., Begossi A. 2001. Ethnozoology of fishing communities from Ilha Grande (Atlantic forest coast, Brazil). Journal of Ethnobiology 21(1): 107-135.

Solarin B.B., Ambrose E.E., Adeogun O., Aniebona F., Opurum S.C., Abass M., Gadzekpo A., Bolaji D.A., 
Orimogunje R.O., Adegbile O.M., Ajulo A.A. 2009. An Overview of Sea Turtle Bycatch in Small-Scale Gillnet Fisheries in Nigeria. In: E. Gilman (Ed.): Proceedings of the Technical Workshop on Mitigating Sea Turtle Bycatch in Coastal Net Fisheries. Honolulu, Gland, Bangkok, Pascagoula: National Marine Fisheries Service, Southeast Fisheries Science Center. 57 p.

Teitze U, Thiele W., Lasch R., Thomsen B., Rihan D. 2005. Economic performance and fishing efficiency of marine capture fisheries. FAO Fisheries Technical Paper 482. Rome: FAO. 68 p.

Tomás J., Castroviejo J., Raga J.A. 1999. Sea turtles in the south of Bioko Island (Equatorial Guinea). Marine Turtle Newsletter 84: 4-6.

Vieweg S., Hughes A.L. Starbird K., Palen L. 2010. Microblogging during two natural hazards events: What Twitter may contribute to situational awareness. In: CHI '10: Proceedings of the SIGCHI Conference on Human Factors in Computing Systems. CHI 2010,
April 10-15, 2010, Atlanta, USA. P. 1079-1088. DOI: $10.1145 / 1753326.1753486$

Wildermann N.E., Barrios-Garrido H. 2012. First Report of Callinectes sapidus (Decapoda: Portunidae) in the diet of Lepidochelys olivacea. Chelonian Conservation and Biology 11(2): 265-268. DOI: 10.2744/CCB-0934.1

Wilson C., Tisdell C. 2005. Knowledge of birds and willingness to support their conservation: an Australian case study. Bird Conservation International 15(3): 225-235. DOI: 10.1017/S0959270905000419

Weiss K., Kenneth R. 2002. "Pope Asked to Call Sea Turtles 'Meat'. In: Los Angeles Times. Home Edition Main News. Part A. P. 2.

Zavala-Norzagaray A.A., Ley-Quiñónez C.P., Espinosa-Carreón T.L., Canizalez-Román A., Hart C.E., Aguirre A.A. 2014. Trace elements in blood of sea turtles Lepidochelys olivacea in the Gulf of California, Mexico. Bulletin of Environmental Contamination and Toxicology 93(5): 536541. DOI: 10.1007/s00128-014-1320-8

\title{
МОРСКИЕ ЧЕРЕПАХИ В ИЛАДЖЕ (НИГЕРИЯ): СОСТОЯНИЕ, СРОКИ НАБЛЮДЕНИЯ И ОСВЕДОМЛЕННОСТЬ О СОХРАНЕНИИ
}

\author{
Дж. А. Огунджоби", О. С. Сурулере
}

\author{
Государственный университет науки и технологий штата Ондо, Нигерия \\ *e-mail:ogunjonson02@gmail.com,ja.ogunjobi@osustech.edu.ng
}

Понимание местным населением мигрирующих видов имеет решающее значение для глобальной программы по сохранению животных и растений. Данное исследование было проведено в 2016-2018 гг. Его целью было (1) изучить демографические характеристики рыбаков, действующих в Илайе (Атлантический океан); (2) определить видовой состав и состояние морских черепах в этом районе; (3) изучить сроки наблюдения животных; (4) оценить поведение рыбаков в отношении морских черепах; (5) оценить осведомленность рыбаков о необходимости сохранения морских черепах; (6) выявить роль демографических факторов на уровень использования населением и сохранения морских черепах. Для выбора мест исследования и респондентов использовалась многоэтапная процедура выборки. Размер выборке включил в себя 364 рыбака из шести местных общин. Данные были собраны с использованием личного интервью, структурированной анкеты и непосредственных наблюдений авторами. Во время каждого интервью респондентам были доступно представлены фотографии шести морских черепах, которые, как сообщается, известны в Нигерии. Собранные данные были проанализированы с использованием описательной статистики, корреляции Пирсона и множественной линейной регрессии. В результате выяснилось, что все рыбаки, промышляющие вдоль Атлантического океана в районе Илайджа, - мужчины. Большинство их (97.2\%) были в возрасте 21-60 лет, более двух третей которых (81.0\%) имели образование. В районе исследования во время питания были отмечены два вида морских черепах (Lepidochelys olivacea, Dermochelys coriacea), хотя L. olivacea встречалась чаще. Эти морские черепахи мигрируют в район Илайджа с апреля и покидают его каждый год в октябре. В этот период некоторые особи L. olivacea были случайно пойманы рыбаками в ловушки внутри сетей, предназначенных для ловли ракообразных, преимущественно относящихся к десятиногим ракообразным (Malacostraca: Decapoda). Около 92.3\% случайно пойманных морских черепах имели удовлетворительный внешний вид с индексом состояния тела $1.77 \pm 0.09$ и $1.36 \pm 0.04$ для самцов и самок. соответственно. Случайно пойманные морские черепахи употребляются местными жителями в качестве мяса. Предпосылками использования морских черепах были возраст рыбаков $(\beta=0.15, \mathrm{p}<0.05)$ и размер семьи $(\beta=-0.02, p<0.05)$, в то время как уровень образования рыбаков являлся предпосылкой мнения по сохранению морских черепах $(\beta=0.02, \mathrm{p}<0.05)$. Кроме того, исследование показало, что существует положительная и значимая связь между личными факторами рыбаков и их обоснованием для отлова морских черепах $(\mathrm{r}=0.23, \mathrm{p}<0.01)$ и осведомленности о сохранении морских черепах $(\mathrm{r}=0.22, \mathrm{p}<0.01)$. Предполагается, что низкий уровень знаний о статусе сохранения морских черепах и его более высокой значимости перед употреблением животных в пищу обусловливает высокое неизбирательное потребление черепах населением и его незначительное участие в сохранении животных. В настоящее время рекомендуется проведения информирования местного населения о сохранении исчезающих морских черепах в районе исследования.

Ключевые слова: водное животное, мигрирующий вид, морские черепахи, поведение рыбаков, штат Ондо 